UDC 621.391

\title{
WIRELESS COOPERATIVE RELAYING WITHOUT MAINTAINING A DIRECT CONNECTION BETWEEN THE SOURCE AND TARGET RECEIVER TERMINALS
}

\author{
Serhii O. Kravchuk, Liana O. Afanasieva \\ Institute of Telecommunication Systems \\ Igor Sikorsky Kyiv Politechnic Institute, Kyiv, Ukraine
}

Background. Improving the efficiency of modern wireless systems requires the development of new wireless technologies and the introduction of new paradigms for building wireless networks, one of which is a distributed approach to network architectures. An important role here is played by the interaction between the wireless terminals or terminals and the base station through additional relay terminals. An important technology that implements this interaction in order to increase the efficiency of communication in a cell is cooperative relaying.

Objective. The aim of the paper is to increase the efficiency of cooperative relaying schemes of information by filling all time phases/slots entering synchronous transmission through the pair number of repeaters.

Methods. We study the structural and functional methods of building a wireless network.

Results. In order to increase the capacity of the traditional cooperative relay scheme, a scheme is proposed with the addition of another auxiliary relay to the existing one so that each of the relays operates only during one of its data transmissions phases. Mathematical models of a number of cooperative relay schemes have been developed, which allow us to describe the main radio technical characteristics of the schemes (SNR, BER and $C$ ). It is proposed that a decision regarding the inclusion of traditional cooperative relaying should occur when a certain distance is reached between the source and the target receiver, when the capacity with and without cooperative relaying are equal. Connecting a cooperative relay scheme without a direct connection allows not only increasing the SNR value, but also maintaining its level only with a slight decrease.

Conclusions. A new scheme of cooperative relaying without maintaining a direct connection between the source terminals and the target receiver is proposed. Compared to the traditional cooperative relay scheme, such a scheme demonstrates more stable radio link characteristics over a wide range of attenuation changes between the source and target receiver terminals.

Keywords: cooperative relaying; auxiliary repeater; wireless data transmission system; link characteristics; wireless terminal.

\section{INTRODUCTION}

Improving the efficiency of modern wireless systems requires the development of new wireless technologies and the introduction of new paradigms for building wireless networks, one of which is a distributed approach to network architectures. The latter led to the emergence of a number of wireless architectures such as ad hoc and mesh, which in modern 4th and 5th generation mobile communication systems made it possible to implement a distributed cellular network with relay [1] - [4]. An important role here is played by the interaction between the wireless terminals or terminals and the base station through additional relay terminals. An important technology that implements this interaction in order to increase the communication efficiency in a cell is cooperative relaying [5].

Using an additional auxiliary relay terminal, the traditional cooperative relay scheme is designed to improve data transfer between two terminals that already have a direct connection, sufficient to transmit at least control information (signaling protocols) between them. When only one radio link between the two original terminals functioned, the data transfer was carried out in only one phase (one time slot). When cooperative relay is activated, that is, the formation of additional bypasses of two radio lines through the auxiliary relay, the entire data transfer will be carried out in two-time phases, which limits the achievable throughput of the traditional scheme with cooperative relay [4], [6].

Great potential lies in the optimization of the two-phase transmission procedure itself during cooperative relaying. Parallel connection of additional repeaters does not lead to a noticeable increase in system efficiency. Most of the works [7] - [11] regarding improving the efficiency of cooperative relaying are aimed at improving the protocol level of the system, for example, the protocol NAF (Non-orthogonal AF) is proposed, which allows transmitting new information from the source already in the second phase, the adaptive protocol AdDF (adaptive decode-and-forward protocol), etc. But increasing the efficiency of cooperative relaying by improving the scheme structure of the wireless part can give a higher gain.

Therefore, the main goal of this work is to increase the efficiency of the cooperative relay scheme by filling out all the time phases/slots by introducing synchronous transmission through a pair of repeaters. This is especially important in a complex heterogeneous subscriber access system, where a large number of terminals are locally located and the formation of an effective direct radio path (direct connection) between two terminals is difficult. 


\section{SYSTEM MODEL FOR TRADITIONAL COOPERATIVE RELAYING}

The traditional scheme of cooperative relaying is shown in Fig. 1. The principle of operation of such a scheme can be represented as follows. A working radio link between two wireless terminals designated as source $S$ (source) and target receiver $D$ (destination), at some point in time deteriorates so much that the bit error rate of the transmitted data reaches its maximum allowable value. In a traditional relay system, with high-quality information transmission from $S$ to $D$, a bypass radio line is formed through the additional relay terminal $R$ (relay). In this case, the basic direct $S-D$ radio link is disconnected, and the entire load on bandwidth falls on $R$, which in most cases is difficult for a complex wireless system with many terminals that perform their individual functions. In cooperative relaying, an additional terminal $R$ is also used. Due to the fact that the basic direct radio link is not disconnected, but is used in conjunction with the formed radio link through the relay $R$, an improvement in the signal-tonoise ratio is obtained at the target receiver $D$ as in the case of diversity reception. However, data transmission in the cooperative relay scheme requires the development of two phases of data transmission: 1$)$ from $S$ to $R$ and $D ; 2$ ) from $S$ and $R$ to $D$. That is, to transmit one message requires the development of two transmissions. Due to the presence of two phases of transmitting the same information in cooperative relaying, the capacity will be two times lower than the capacity of a direct radio link between $S$ and $D$ without additional relaying. But this does not mean that a particular instantaneous value of the capacity at the cooperative relay will be less than the capacity of a direct radio link, as the bit error rate of the latter will be greater than when the cooperative relay mechanism is turned on.

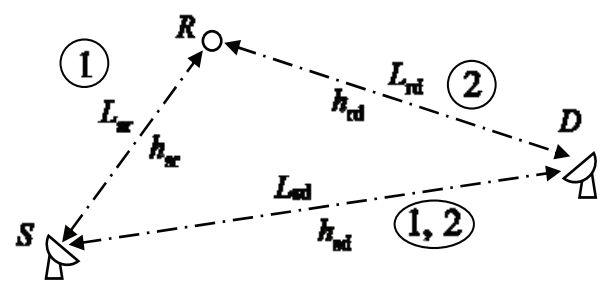

Fig. 1. The traditional scheme of cooperative relaying

Consider a wireless system with cooperative relaying, where it is possible to form radio channels with additive white Gaussian noise (AWGN) between the terminals using a simple AF (Amplify-and-Forward) protocol [5]. All nodes are half duplex, so they cannot transmit and receive at the same time. Physical connections between terminals subject to block fading are modeled as independent, cyclically symmetric complex Gaussian random variables with zero mean with unit dispersion. A classical quasistatic channel is assumed here, which remains constant during the transmission of one-time interval, but changes independently of one slot to another. Such an approximation corresponds to a system in which the coherence time is less than the frame interval. In traditional cooperative relaying, a frame consists of 2 slots of $l$ symbols, denoted by $x_{i}$, where $i=1,2$. We focus on two consecutive time intervals that correspond to the basic cooperative frame. Using the results of [1] for such a system, the transmitted and received signals can be written in the following form:

$$
\begin{gathered}
y_{s r}^{(1)}=\sqrt{P_{s}^{(1)}} h_{s r}^{(1)} x_{1}+n_{s r}^{(1)} ; \\
y_{s d}^{(1)}=\sqrt{P_{s}^{(1)}} h_{s d}^{(1)} x_{1}+n_{s d}^{(1)} ; \\
y_{r d}^{(2)}=\sqrt{P_{r}^{(2)}} h_{r d}^{(2)} x_{2}+n_{r d}^{(2)} ; \\
y_{s d}^{(2)}=\sqrt{P_{s}^{(2)}} h_{s d}^{(2)} x_{2}+\sqrt{P_{r}^{(2)}} h_{r d}^{(2)}\left(G y_{s r}^{(1)}\right)+n_{s d}^{(2)} ;
\end{gathered}
$$

where $y_{s r t}^{(t)}, y_{\sigma r}^{(t)}$ are the symbols received from the source at the point of the target receiver and relay, respectively; $y_{r d}^{(t)}$ symbols received from the repeater to the target receiver; $t-$ time slot number $(1,2) ; h_{k I}^{(\tau)}$ - channel transfer coefficient for the physical communication line of the $t$-slot between $k$ and $l$ nodes; $y_{r d}^{(2)}=n_{k l-}^{(t)}$ noise component; $P_{s}^{(t)}, P_{r}^{(t)}$ - the transmitted power from the source and repeater in slot $t$, respectively. Usually, a general power constraint of the following form is taken: $\mathrm{P}=P_{s}^{(1)}+P_{s}^{(2)}+P_{r}^{(2)}$. G - transfer coefficient at the repeater, which can be written as $\left(1 / P_{s}^{(1)}\left|h_{s r}^{(1)}\right|^{2}+1\right)^{1 / 2}$, and the product, with which $\left(G y_{r d}^{(1)}\right)$ corresponds to symbols $x_{2}$.

The signal-to-noise ratio (SNR) for a traditional scheme can be obtained from the system of equations (1). We will use ready-made solutions, for example, according to [12], [13] the end-to-end SNR of the indirect line $S-R-D$ can be written as

$$
\mathrm{SNR}_{s r d}=\left(\mathrm{SNR}_{s r} \mathrm{SNR}_{r d}\right) /\left(\mathrm{SNR}_{s r}+\mathrm{SNR}_{r d}+1\right)
$$

where $\operatorname{SNR}_{g r^{*}}=P_{s}^{(1)}\left|h_{s r^{(1)}}^{(1)}\right|^{2} / N_{0}$ and $\mathrm{SNR}_{r d}=P_{r}^{(2)}\left|h_{r d}^{(2)}\right|^{2} / N_{0}$ - signal-to-noise ratio at the input of the repeater receiver and the target receiver, respectively; $N_{0}$ is the intrinsic noise power in the passband of the receiver.

Assuming that the maximum ratio combining (MRC) method is used in the node of the target receiver, the total SNR in the target receiver can be written as

$$
\mathrm{SNR}_{\text {coop }}=\mathrm{SNR}_{s d}+\left(\mathrm{SNR}_{s r} \mathrm{SNR}_{r d}\right) /\left(\mathrm{SNR}_{s r}+\mathrm{SNR}_{r d}+1\right) .
$$

In the case of using multiple relay terminals $R_{i}$ (where $i=1$, $\ldots, N$ ) connected in parallel to each other, the total signal-tonoise ratio can be defined as follows [4], [5]:

$$
\begin{aligned}
& \mathrm{SNR}_{\text {coop }}=\mathrm{SNR}_{s d}+ \\
& +\sum_{i=1}^{N}\left[\left(\mathrm{SNR}_{s r i} \mathrm{SNR}_{r i d}\right) /\left(\mathrm{SNR}_{s r i}+\mathrm{SNR}_{r i d}+1\right)\right]
\end{aligned}
$$

When using the method of choosing the best repeater that reaches the highest SNR, we have 


$$
\begin{aligned}
& \mathrm{SNR}_{\text {coop }}=\mathrm{SNR}_{s d}+ \\
& +\max _{i}\left[\left(\mathrm{SNR}_{\text {sri }} \mathrm{SNR}_{\text {rid }}\right) /\left(\mathrm{SNR}_{\text {sri }}+\mathrm{SNR}_{\text {rid }}+1\right)\right] .
\end{aligned}
$$

The capacity of the scheme with cooperative relaying during its operation for two time slots (phases) will be respectively two times less than the bandwidth of the direct base radio link $S-D$. However, it should be borne in mind that the cooperative relay mechanism is only started when the bit error rate on the base $S$ - $D$ radio link becomes critically large, which does not allow the transmission of the required information stream (data rate) to continue with a given quality level. That is, in spite of the lower value of the possible maximum transmission rate during cooperative relaying, due to a decrease in the probability of bit errors, the overall data transfer rate will be greater than only in the basic $S$ - $D$ radio link. Capacity in cooperative relaying can be expressed as follows [1], [14]:

$$
C_{\text {coop }}=\Delta f \log _{2}\left(1+\mathrm{SNR}_{\text {coop }}\right) / 2 \text {, }
$$

where $\Delta f$ - pass-through frequency band of the receiver.

Increase the capacity of cooperative relaying schemes can be almost doubled (in Equation (2) is removed denominator) complicating the scheme by adding one more auxiliary repeater $R_{2}$ to the existing $R_{1}$ (Fig. 2). But in this case, the auxiliary relay $R_{2}$ works in antiphase to $R_{1}$, providing information transfer during those phases (time slots) when $R_{1}$ does not transmit information to $D$ (phase 1). Thus, the signal from $S$ and from one of the repeaters alternately will be continuously received at the target receiver during any phase. Here, data transfer occurs during each of two phases: 1) from $S$ to $R_{1}$, from $S$ to $D$, from $R_{2}$ to $D ; 2$ ) from $S$ to $R_{2}$, from $S$ to $D$, from $R_{1}$ to $D$. Each of the repeaters should work only during one of its phases of data transfer, which is not always possible to implement.

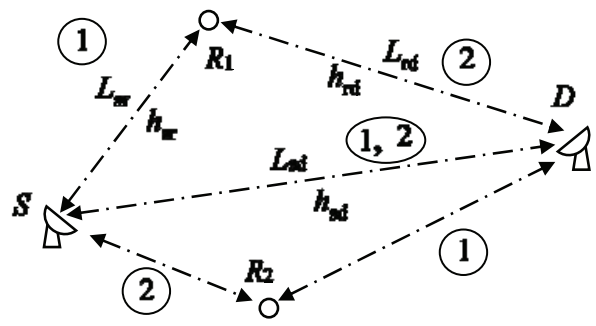

Fig. 2. Cooperative relay scheme with two relays operating synchronously

\section{A MODEL OF A COOPERATIVE RELAY SYSTEM WITHOUT MAINTAINING A DIRECT CONNECTION BETWEEN THE SOURCE AND THE TARGET RECEIVER}

A cooperative relay scheme for a wireless system in which there is no direct connection between the terminals with the source and the target receiver is shown in Fig. 3. Here, the working radio link between $S$ and $D$ cannot be formed directly, since there is either no direct line of sight between them, or there is not enough energy to form an indirect channel. Therefore, the basic connected radio link between $S$ and $D$ is formed through an additional relay terminal $R_{0}$. Thus, data transmission from the source to the target receiver will occur in two phases: $S-R_{0}$ and $R_{0}-D$. If the signal quality drops to its critical value on the $R_{0}-D$ radio line, then the cooperative relay technique can be applied by using one more additional relay $R_{1}$. Then, by analogy with the system of equations (1) for a system without line of sight between $S$ and $D$, the transmitted and received signals can be written in the following form:

$$
\begin{aligned}
y_{s r 0}^{(1)} & =\sqrt{P_{s}^{(1)}} h_{s r 0}^{(1)} x_{1}+n_{s r 0}^{(1)} ; \\
y_{s r 1}^{(1)} & =\sqrt{P_{s}^{(1)}} h_{s r 1}^{(1)} x_{1}+n_{s r 1}^{(1)} \\
y_{r 0 d}^{(2)} & =\sqrt{P_{r 0}^{(2)}} h_{r 0 d}^{(2)} x_{2}+n_{r 0 d}^{(2)} \\
y_{r 1 d}^{(2)} & =\sqrt{P_{r 1}^{(2)}} h_{r 1 d}^{(2)} x_{2}+n_{r 1 d}^{(2)} ; \\
y_{s d}^{(2)} & =\sqrt{P_{r 0}^{(2)}} h_{r 0 d}^{(2)}\left(G y_{s r 0}^{(1)}\right)+ \\
+\sqrt{P_{r 1}^{(2)}} h_{r 1 d}^{(2)} & \left(G y_{s r 1}^{(1)}\right)+n_{r 0 d}^{(2)}+n_{r 1 d}^{(2)} ;
\end{aligned}
$$

The general power limit for such a cooperative relay scheme can be defined as follows $\mathrm{p}=P_{s}^{(1)}=P_{r 0}^{(2)}+P_{r 1}^{(2)}$.

The signal-to-noise ratio SNR for this scheme can be obtained from the system of equations (3). Assuming that the MRC method is used at the destination receiver node, the total SNR can be written as

$$
\begin{aligned}
\mathrm{SNR}_{\text {coop }}= & \left(\mathrm{SNR}_{s r 0} \mathrm{SNR}_{r 0 d}\right) /\left(\mathrm{SNR}_{s r 0}+\mathrm{SNR}_{r 0 d}+1\right)+ \\
& +\left(\mathrm{SNR}_{s r 1} \mathrm{SNR}_{r 1 d}\right) /\left(\mathrm{SNR}_{s r 1}+\mathrm{SNR}_{r 1 d}+1\right),
\end{aligned}
$$

where the signal-to-noise ratios for different spans can be written as

$$
\begin{aligned}
& \mathrm{SNR}_{s r 0}=P_{s}^{(1)}\left|h_{s r 0}^{(1)}\right|^{2} / N_{0}: \quad \mathrm{SNR}_{r 0 d}=P_{r 0}^{(2)}\left|h_{r 0 d}^{(2)}\right|^{2} / N_{0} ; \\
& \mathrm{SNR}_{s r 1}=P_{s}^{(1)}\left|h_{s r 1}^{(1)}\right|^{2} / N_{0} ; \quad \operatorname{SNR}_{r 1 d}=P_{r 1}^{(2)}\left|h_{r 1 d}^{(2)}\right|^{2} / N_{0} \text {. }
\end{aligned}
$$

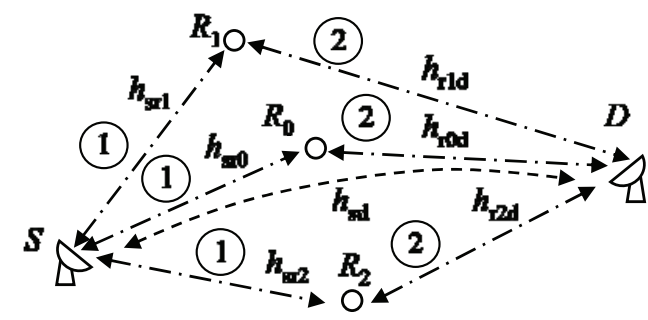

Fig. 3. Cooperative relay scheme for a wireless system in which there is no direct connection between the terminals with the source and the target receiver

When the proposed scheme works with cooperative relaying, its capacity will not be twice as small (as in the case of the traditional scheme) than the capacity of the direct base radio line, which is determined by the signal-to-noise ratio in the $R_{0}-D$ section. This is due to the fact that in this case at least two phases are required to transfer data between $S$ and $D$, but for each of them both the source and the repeaters carry out 
the transmission of new data packets each time. Thus, the capacity of the cooperative relay scheme under consideration can be expressed as $C_{\text {coop }}=\Delta f \log _{2}\left(1+\mathrm{SNR}_{\text {coop }}\right)$.

Further parallel build-up of additional relay nodes, for example, $R_{2}$ in Fig. 3, gives a similar effect, as in the case of the traditional scheme of cooperative relaying. The expression for the signal-to-noise ratio in this case can be written as

$$
\begin{aligned}
& \mathrm{SNR}_{\text {coop }}=\left(\mathrm{SNR}_{s r 0} \mathrm{SNR}_{r 0 d}\right) /\left(\mathrm{SNR}_{\text {sr } 0}+\mathrm{SNR}_{r 0 d}+1\right)+ \\
& +\sum_{i=1}^{N}\left[\left(\mathrm{SNR}_{\text {sri }} \mathrm{SNR}_{r i d}\right) /\left(\mathrm{SNR}_{\text {s ri }}+\mathrm{SNR}_{r i d}+1\right)\right] .
\end{aligned}
$$

\section{MODEL OF A COOPERATIVE RELAY SYSTEM WITH MULTIPLE SERIAL RELAYS}

The cooperative relay scheme for a wireless system that uses several repeaters arranged in series is shown in Fig. 4. Here, when another relay $R_{2}$ is introduced into the additional radio relay path, sequentially to the first $R_{1}$, a more energyefficient connection is created (provided that the characteristics of $R_{2}$ are not worse than the characteristics of $\left.R_{1}\right)$. However, the data transfer is already carried out in three phases, which limits the capacity of such a connection. For the cooperative relay scheme under consideration, the transmitted and received signals can be written in the following form:

$$
\begin{aligned}
& y_{s r 0}^{(1)}=\sqrt{P_{s}^{(1)}} h_{s r 0}^{(1)} x_{1}+n_{s r 0}^{(1)} ; \\
& y_{s r 1}^{(1)}=\sqrt{P_{s}^{(1)}} h_{s r 1}^{(1)} x_{1}+n_{s r 1}^{(1)} \\
& y_{r 0 d}^{(2)}=\sqrt{P_{r 0}^{(2)}} h_{r 0 d}^{(2)} x_{2}+n_{r 0 d}^{(2)} \\
& y_{r 1 r 2}^{(2)}=\sqrt{P_{r 1}^{(2)}} h_{r 1 r 2}^{(2)} x_{2}+n_{r 1 r 2}^{(2)} \\
& y_{r 2 d}^{(3)}= \sqrt{P_{r 2}^{(3)}} h_{r 2 d}^{(3)} x_{3}+n_{r 2 d}^{(3)} ; \\
& y_{s d}^{(3)}=\sqrt{P_{r 0}^{(2)}} h_{r 0 d}^{(2)}\left(G_{1} y_{s r 0}^{(1)}\right)+ \\
& \quad+\sqrt{P_{r 2}^{(3)}} h_{r 2 d}^{(3)}\left(G_{2} y_{r 1 r 2}^{(1)}\right)+n_{r 0 d}^{(3)}+n_{r 2 d}^{(3)} .
\end{aligned}
$$

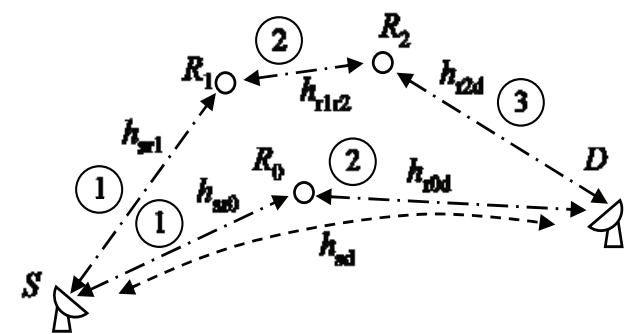

Fig. 4. A cooperative relay scheme for a wireless system that uses multiple repeaters arranged in series

Assuming that the MRC method is used in node $D$, the total SNR can be written as

$\mathrm{SNR}_{\text {coop }}=\left(\mathrm{SNR}_{\text {sr } 0} \mathrm{SNR}_{r 0 d}\right) /\left(\mathrm{SNR}_{\text {sr } 0}+\mathrm{SNR}_{r 0 d}+1\right)+$

$$
+\left(\mathrm{SNR}_{r 1 r 2} \mathrm{SNR}_{r 2 d}\right) /\left(\mathrm{SNR}_{r 1 r 2}+\mathrm{SNR}_{r 2 d}+1\right) \text {. }
$$

The capacity of the proposed scheme with cooperative relaying during its operation in three phases will be two times less (as in the case of the traditional circuit) than the bandwidth of the direct base radio line, which is determined by the signal-to-noise ratio in the $R_{0}-D$ section. To determine the capacity of the cooperative relay scheme under consideration, expression (2) can be used.

\section{SIMULATION RESULTS AND THEIR ANALYSIS}

Numerical simulation of cooperative relay schemes was carried out in the Matlab software package. We used the standard model of attenuation from the logarithm of distance (Log-distance path loss) for a wireless radio link in a microcellular system (cell radius does not exceed $500 \mathrm{~m}$ ), as well as a model of a flat Earth's surface under standard atmospheric conditions. The calculations were carried out for radio links with the following characteristics: central operating frequency of $5 \mathrm{GHz}$; end-to-end frequency band for $S$ and $D$ $10 \mathrm{MHz}$, for all repeaters - $5 \mathrm{MHz}$; used type of modulation QAM; maximum instantaneous transmitter powers for $S-100$ $\mathrm{mW}$, for repeaters - $50 \mathrm{~mW}$; antenna gain for $S-20 \mathrm{dBi}$, for repeaters $-16 \ldots 20 \mathrm{dBi}$; the noise figure of the receivers is 5 ... $6 \mathrm{~dB}$.

The perpendicular distance to the location of the repeaters from the line of sight between $S$ and $D$ is $300 \mathrm{~m}$; for any length of the radio link between $S$ and $D$, the point of intersection with the perpendicular to the location of the auxiliary repeater is in the middle of the $S$ - $D$ radio link.

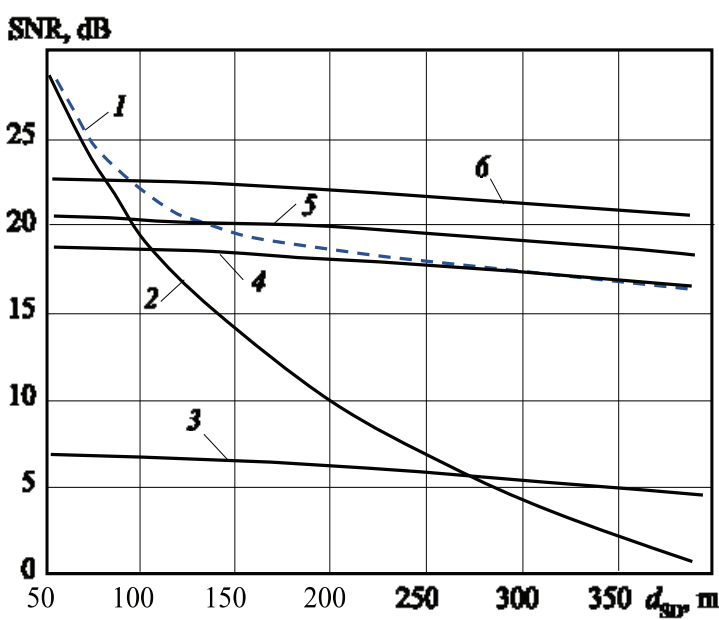

Fig. 5. The dependence of the signal-to-noise ratio SNR on the distance between $S$ and $D d_{\mathrm{SD}}$ for different radio links: 1 - traditional cooperative relaying; 2 - only the radio link between $S$ and $D ; 3$ - a radio link between an additional relay $R_{1}$ and $D$ for the case of cooperative relaying without a direct connection between $S$ and $D ; 4$ - cooperative relaying without a direct relationship between $S$ and $D ; 5$ - radio link between $R$ and $D ; 6$ - radio link between $S$ and $R$

The simulation results are presented in the form of the dependences of the main characteristics of the SNR, BER, and $\mathrm{C}$ radio links on the distance between $S$ and $D d_{\mathrm{SD}}$ (Fig. 5, 6 and 7), an increase in which simulates the deterioration of the quality of the radio link between $S$ and $D$.

All figures show the characteristics of the radio link between $S$ and $D$ in the absence of cooperative relaying. As 
the distance between $S$ and $D$ increases, the losses on the radio path increase and the SNR on the receiving side $D$ decreases (curve 2 in Fig. 5), which leads to an increase in the probability of a bit error BER (curves 2, 4 in Fig. 6) and a decrease in channel capacity $C$ (curve 1 in Fig. 7).

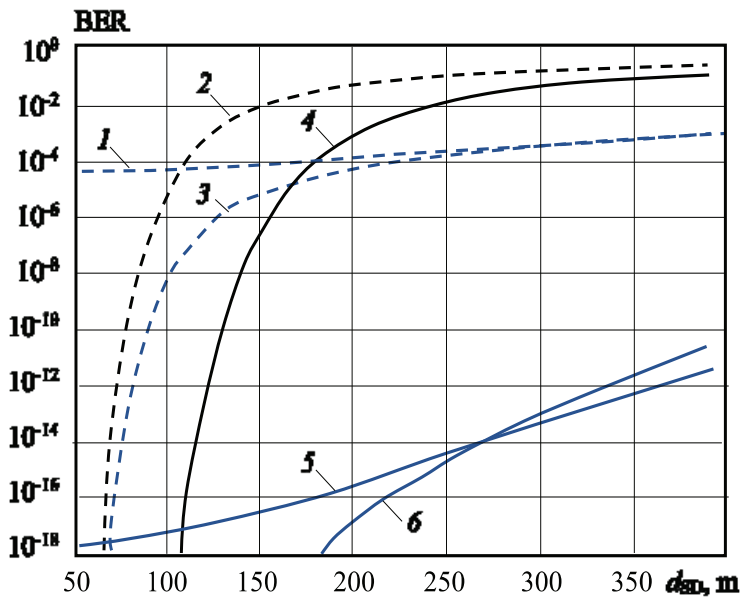

Fig. 6. Dependence of BER on the distance between $S$ and $D d_{\mathrm{SD}}$ for two types of modulations QAM 4 (curves 4, 5 and 6) and QAM 16 (curves 1, 2 and 3) using different cooperative relay schemes: 1, 5 - cooperative relay without direct the relationship between $\mathrm{S}$ and $\mathrm{D} ; 2,4$ - lack of cooperative relaying; 3, 6 - traditional cooperative relaying

When the traditional cooperative relaying scheme is switched on (Fig. 1), an increase in SNR is observed (curve 1 in Fig. 5) from a corresponding decrease in BER (curves 3, 6 in Fig. 6), which makes it possible to increase the value of $C$ (curve 2 in Fig. 7). From the SNR analysis (curves 1 and 2 in Fig. 5) it is seen that the cooperative relay mechanism allows increasing the SNR value by $D$, and the greater the deterioration (attenuation) on the line of sight between $S$ and $D$, the greater the gain from switching on the cooperation scheme. In this case, for connected auxiliary relays, the change in the values of $\mathrm{SNR}_{\mathrm{sr}}$ and $\mathrm{SNR}_{\mathrm{rd}}$ will change slightly (curves 5 and 6 in Fig. 5, respectively). For example, with $d_{\mathrm{SD}}$ $=100 \mathrm{~m}$ we have a gain in SNR of $3 \mathrm{~dB}$, and with $d_{\mathrm{SD}}=300 \mathrm{~m}$ we have a gain in SNR of $14 \mathrm{~dB}$. But in both cases, a sufficiently low BER value is provided for a given type of modulation (Fig. 6). This raises the logical question: at what values of $d_{\mathrm{SD}}$ will it be rational to decide on the inclusion of the mechanism of traditional cooperative relaying? The answer, perhaps, will be the result of bandwidth modeling. For small $d_{\mathrm{SD}}$ values, when the SNR is still sufficiently high (this SNR is not less than its threshold for a given type of modulation) on the line of sight between $S$ and $D$, the throughput of such a line of sight will also be sufficient to transmit data of the required transmission rate (BER the channel also does not exceed its allowable level). The introduction of a cooperative relay mechanism here is not only a premature and redundant (inefficient solution), but can also lead to a drop in the scheme capacity due to the presence of 2 phases of data transmission in it (curve 2 in Fig. 7). For example, with $d_{\mathrm{SD}}=150 \mathrm{~m}$, there is already a gain in SNR of $5 \ldots 6 \mathrm{~dB}$ and a corresponding decrease in BER, but the capacity for cooperative relaying will still be less (by 20
Mbps) than without it. Therefore, we proposed that the point of decision-making on the inclusion of traditional cooperative relaying will be $d_{\mathrm{SD}}=225 \mathrm{~m}$, when capacity with and without cooperative relaying will be practically equal.

Engaging the cooperative relay scheme with two repeaters that operate synchronously (Fig. 2) allows you to immediately begin to increase the capacity (curve 4 in Fig. 7), since here the data transfer process, although it occurs in two phases, is performed in parallel and not sequentially. Therefore, the decision to include such a cooperative scheme can be made much earlier, when the drop-in capacity on the radio line without cooperative relaying decreases by $20 \ldots 40 \%$ (without reaching its boundary value), for example, with $d_{\mathrm{SD}}=90 \ldots 100$ m.

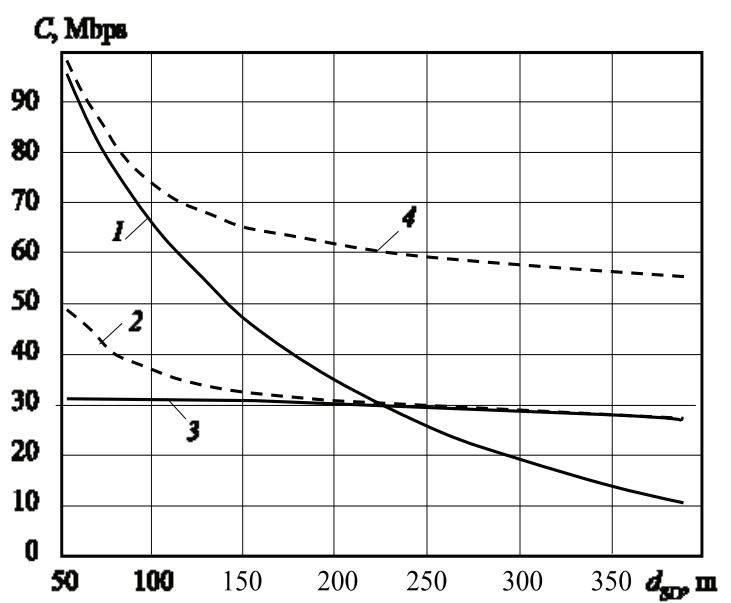

Fig. 7. The dependence of the capacity $C$ on the distance between $S$ and $D$ $d_{\mathrm{SD}}$ for different cooperative relay schemes: 1 - only the radio link between S and $\mathrm{D}$, there is no cooperative relay; 2 - traditional cooperative relaying; 3 cooperative relay without the direct connection between $\mathrm{S}$ and $\mathrm{D} ; 4$ cooperative relay with two relays operating synchronously

When you turn on the cooperative relay scheme for a wireless system, where there is no direct connection between the terminals with the source and the target receiver (Fig. 3), the initial working radio link, the degradation of which leads to the need to turn on the cooperative relay, is the $S-R_{0}-D$ relay chain. In this case, connecting the auxiliary relay $R_{1}$ leads to smaller fluctuations in the characteristics of the radio links of the circuit than in the case of traditional cooperative relaying. So, the inclusion of a cooperative relay scheme without a direct connection allows not only increasing the SNR value (curve 4 in Fig. 5), but also maintaining its level only with a slight decrease. Note that for small $d_{\mathrm{SD}}$ values (up to $200 \mathrm{~m}$ ), the SNR of the considered circuit is lower than the SNR of the traditional scheme (curve 1 in Fig. 5). But at higher $d_{\mathrm{SD}}$ SNRs, all cooperative relay schemes become almost the same. The SNR ratio for the radio link between the additional repeater $R_{1}$ and $D$ for the case of cooperative relay without the presence of a direct connection is shown as curve 3 in Fig. 5. In this case, for small $d_{\mathrm{SD}}$ values, when the SNR does not increase significantly, the BER characteristic is better than for the case without cooperative relaying and worse than for the case of traditional cooperative relaying (curves 1 and 5 in Fig. 6). But with a further increase in $d_{\mathrm{SD}}$, the BER characteristic becomes 
almost equal to BER for the case of traditional cooperative relaying. Hence, the capacity characteristic of a circuit without a direct connection is fully consistent with the BER characteristic for the same scheme (curve 3 in Fig. 7). Thus, this cooperation scheme allows you to maintain stable characteristics of the radio lines that are included in it, and the decision point for its inclusion can be determined, as in the case of the traditional cooperative relay scheme.

\section{CONCLUSION}

In order to increase the throughput of the traditional cooperative relay scheme, a scheme is proposed with the addition of another auxiliary relay to the existing one, so that each relay works only during one of its data transmissions phases (Fig. 2).

A new scheme for cooperative relaying without maintaining a direct connection between the terminals of the source and the target receiver is proposed (Fig. 3). Compared to the traditional cooperative relay scheme, such a scheme demonstrates more stable radio link characteristics over a wide range of attenuation changes between the source and target receiver terminals.

A cooperative relay scheme for a wireless system is presented, which uses several repeaters arranged in series.

Mathematical models of a number of cooperative relay schemes have been developed that allow us to describe the main radio technical characteristics of the schemes (SNR, BER and $C$ ).

Based on the developed mathematical models, modeling of the characteristics of the traditional and proposed schemes of cooperative relaying is carried out.

Analysis of the data obtained as a result of modeling showed the following. The cooperative relay mechanism allows you to increase the value of SNR, and the greater the deterioration (attenuation) on the radio link between $S$ and $D$, the greater the gain from the inclusion of the cooperation scheme.

It is proposed that a decision regarding the inclusion of traditional cooperative relaying should occur when a certain distance between $S$ and $D$ is reached $\left(d_{\mathrm{SD}}=225 \mathrm{~m}\right)$, when the throughputs with and without cooperative relaying will be equal.

Connecting a cooperative relay scheme without a direct connection allows not only increasing the SNR value, but also maintaining its level only with a slight decrease. Moreover, at small $d_{\mathrm{SD}}$ values, the SNR of the considered circuit is lower than the SNR of the traditional circuit, but at higher $d_{\mathrm{SD}}$ values the SNR of all cooperative relay schemes becomes almost the same.

\section{ACKNOWLEDGMENT}

This work is carried out within the framework of state research projects (No 2120, state registration number (SRN) 0118 U003521 "Scientific and technical basis for building new over-horizon communications relay systems using artificial structures and aeroplatform") on request of the Ministry of Education and Science of Ukraine.

\section{REFERENCES}

[1] Cooperative Communications for Improved Wireless Network Transmission: Framework for Virtual Antenna Array Applications edited by M. Uysal. Hershey, New York: Information Science Reference, 2010, 632 p. (ISBN 978-1-60566-665-5).

[2] 5G NR: The Next Generation Wireless Access Technology / edited by E. Dahlman, S. Parkvall, J. Skold, London: Academic Press, 2018, 468 p. (ISBN 978-0-12-814323-0).

[3] Signal processing for $5 \mathrm{G}$ : algorithms and implementations / edited by Fa-L. Luo, C. Zhang, Chichester: John Wiley, 2016, 600 p. (ISBN 9781119116479).

[4] M.Y. Ilchenko, S.O. Kravchuk, Telecommunication systems: Kyiv, Naukova dumka, 2017, 736 p. (ISBN: 978-966-00-1566-1), (in Ukraine).

[5] Cooperative Communications and Networking, by edited K.J.R. Liu, A.K. Sadek, W. Su, A. Kwasinski, Cambridge: Cambridge University Press, 2009, 642 p. (ISBN-13 978-0-511-46548-2).

[6] L.A. Afanasieva, S.O. Kravchuk, D.A. Minochkin, "Outage probability in wireless communication system with multiple antenna cooperative retransmission", Scientific papers coll. of the Military Institute of Kyiv National University. Shevchenko, Issue 51, pp. 19-26 (2016).

[7] L.O. Aphanasieva, S.O. Kravchuk, "Adaptive relay protocol for cooperative networks", Dig. of the 13th International Scientific conf. "Modern Challenges in Telecommunications", april 15-19, 2019, Kyiv, Ukraine, $\quad-\quad$ pp. 192-194 (https://scholar.google.com.ua/scholar?oi= bibs\&cluster= $6146738400389784355 \& \mathrm{btnI}=1 \& \mathrm{hl}=\mathrm{uk})$

[8] L.O. Aphanasieva, S.O. Kravchuk, I.I. Shevchenko, K.I. Rystsova, "Coded cooperation scheme", Dig. of the 12th International Scientific conf. "Modern Challenges in Telecommunications", April 16-20, 2018, Kyiv, Ukraine, pp. 211-213 (2018) (https://scholar.google.com.ua/scholar?oi=bibs\&cluster= $7895794699776003570 \&$ btnI $=1 \&$ hl $=$ uk).

[9] A.V. Rizhko, S.O. Kravchuk, "Investigation of ability to increasing quality of service for IEEE $802.16 \mathrm{j}$ multishop repeater networks", Dig. of the Eleventh International Scientific conf. "Modern Challenges in Telecommunications", April 18-21, 2017, Kyiv, Ukraine, pp. 163-165 (2017)

(https://scholar.google.com.ua/scholar?oi=bibs\&cluster=119825474251 95246610\&btnI=1\&hl=uk).

[10] E. Zimmermann, P. Herhold, G. Fettweis, On the Performance of Cooperative Relaying Protocols in Wireless Networks, European Transactions on Telecommunications 16(1), 5-16 January 2005, (DOI: 10.1002/ett.1028).

[11] P. Herhold, E. Zimmermann, G. Fettweis, "A Simple Cooperative Extension to Wireless Relaying", International Zurich Seminar on Communications, 24 August, Zurich, Switzerland (2004) (DOI: 10.1109/IZS.2004.1287382).

[12] P. Kiratipongvooth, S. Sittichivapak, "Bit Error Probability of Cooperative Diversity for M-ary QAM OFDM-based system with Best Relay Selection", 2011 International Conference on Information and Electronics Engineering IPCSIT vol.6, IACSIT Press, Singapore, pp. 95 99 (2011).

[13] E. Aydm, H. Illian, "SNR-based Relay Selection Scheme for Cooperative Relay Networks", International Wireless Communications \& Mobile Computing Conference (IWCMC 2015), pp. 448-453 (DOI: 10.1109/IWCMC.2015.7289125).

[14] S.A. Kravchuk, "Comparison of ergodic bandwidth of traditional singlespan, multi-span and cooperative broadband radio access networks with relay", Dig. of the Tenth International Scientific conf. "Modern Challenges in Telecommunications", april 25-27, 2007, Kyiv, Ukrane. K.: Himjest, 2007, p. 55 
Кравчук С.О., Афанасьєва Л.О.

Безпроводова кооперативна ретрансляція без підтримки безпосереднього з'єднання між терміналами джерела і цільового приймача

Проблематика. Підвищення ефективності сучасних безпроводових систем вимагає розвитку нових безпроводових технологій і впровадження нових парадигм побудови безпроводових мереж, однією з яких є розподілений підхід до мережних архітектур. Тут важливу роль відіграє взаємодія між безпроводовими терміналами або терміналами і базовою станцією за допомогою додаткових ретрансляційних терміналів. Важливою технологією, що реалізує таку взаємодію 3 метою підвищення ефективності зв'язку в стільнику, $є$ кооперативна ретрансляція.

Мета дослідження. Метою роботи є підвищення ефективності схеми кооперативної ретрансляції шляхом інформаційного наповнення всіх часових фаз/слотів, ввівши синхронну передачу через парну кількість ретрансляторів.

Методика реалізації. Досліджуються структурно-функціональні методи побудови безпроводової мережі.

Результати дослідження. 3 метою підвищення пропускної спроможності традиційної схеми кооперативної ретрансляції запропонована схема 3 введенням ще одного допоміжного ретранслятора до наявного так, що кожен 3 ретрансляторів працює тільки під час однієї своєї фази передачі даних. Розроблено математичні моделі ряду схем кооперативної ретрансляції, які дають можливість розрахувати основні радіотехнічні характеристики схем (SNR, BER i C). Запропоновано, що прийняття рішення щодо включення традиційної кооперативної ретрансляції має відбуватися при досягненні певного значення відстані між джерелом і цільовим приймачем, коли пропускні спроможності з і без кооперативної ретрансляції будуть однаковими. Підключення схеми кооперативної ретрансляції без безпосереднього з'єднання дозволяє не тільки підвищити значення SNR, але й утримувати його рівень тільки з незначним зниженням.

Висновки. Запропоновано нову схему кооперативної ретрансляції без підтримки безпосереднього з'єднання між терміналами джерела і цільового приймача. У порівнянні з традиційною схемою кооперативної ретрансляції така схема демонструє більш стабільні характеристики радіоліній в широкому діапазоні зміни загасання між терміналами джерела i цільового приймача.

Ключові слова: кооперативна ретрансляція; допоміжний ретранслятор; безпроводова система передачі даних; характеристики радіолінії; безпроводовий термінал.

Кравчук С.А., Афанасьева Л.А.

Беспроводная кооперативная ретрансляция без поддержания непосредственного соединения между терминалами источника и целевого приемника

Проблематика. Повышение эффективности современных беспроводных систем требует развития новых беспроводных технологий и внедрения новых парадигм построения беспроводных сетей, одной из которых является распределенный подход к сетевым архитектурам. Здесь важную роль играет взаимодействие между беспроводными терминалами или терминалами и базовой станцией посредством дополнительных ретрансляционных терминалов. Важной технологией, реализующей такое взаимодействие с целью повышения эффективности связи в соте, является кооперативная ретрансляция.

Цель исследования. Целью работы является повышение эффективности схемы кооперативной ретрансляции путем информационного заполнения всех временных фаз/слотов, введя синхронную передачу через парное количество ретрансляторов.

Методика реализации. Исследуются структурно-функциональные методы построения беспроводной сети.

Результаты исследования. С целью повышения пропускной способности традиционной схемы кооперативной ретрансляции предложена схема с добавлением еще одного вспомогательного ретранслятора к имеющемуся так что каждый из ретрансляторов работает только во время одной своей фазы передачи данных. Разработаны математические модели ряда схем кооперативной ретрансляции, которые позволяют описать основные радиотехнические характеристики схем (SNR, BER и C). Предложено, что принятие решения касательно включения традиционной кооперативной ретрансляции должно происходить при достижении определенного значения расстояния между источником и целевым приемником, когда пропускные способности с и без кооперативной ретрансляции будут равны. Подключение схемы кооперативной ретрансляции без непосредственного соединения позволяет не только повысить значение SNR, но и удерживать его уровень только с незначительным снижением.

Выводы. Предложена новая схема кооперативной ретрансляции без поддержания непосредственного соединения между терминалами источника и целевого приемника. По сравнению с традиционной схемой кооперативной ретрансляции такая схема демонстрирует более стабильные характеристики радиолиний в широком диапазоне изменения затухания между терминалами источника и целевого приемника.

Ключевые слова: кооперативная ретрансляция; вспомогательный ретранслятор; беспроводная система передачи данных; характеристики радиолинии; беспроводный терминал. 